\title{
ANALISA PEMBELAJARAN AKSARA BALI BERBASIS AUGMENTED REALITY MENGGUNAKAN MODEL KANO DAN MODEL
}

\author{
Gerson Feoh $^{1}$ Christian Tonyjanto $^{2}$ Rheza Paleva Wiryadikara $^{3}$ \\ Program Studi Teknik Informatika ${ }^{1)}{ }^{3)}$ Program Studi Sistem Informasi ${ }^{2)}$ \\ Universitas Dhyana Pura \\ gerson.feoh@undhirabali.ac.id ${ }^{1)}$ christiantonyjanto@undhirabali.ac.id ${ }^{2)}$
}

\begin{abstract}
This study aims to analyze the implementation of Augmented Reality (AR-Learning) in the learning of Balinese Script in elementary school age students. The Balinese script as one of the regional scripts that has become one of the regional writings to be introduced compulsorily to school children from elementary school through high school in the province of Bali. The conventional learning model introducing Balinese Script is often unsuccessful due to the lack of interesting process of introducing and learning the Balinese Script. For this reason, alternative learning methods using technology can be implemented, one of which uses Augmented Reality, or better known as AR-Learning. By utilizing Android-based smartphones, learning Balinese script will certainly be more fun for elementary school students. In this study, students of grade 3 SDN 1 B.B Agung used a case study in this research. The results of this study are the Balinese Augmented Reality card complete with an analysis of Android-based Balinese learning implementation with Augmented Reality technology using the Kano Model to categorize the attributes of AR-Learning user satisfaction and the USE Questionnaire Model for evaluation of usability recommendations for applications based on 4 quality dimensions namely the dimensions of usefulness, ease of use, ease of learning, and satisfaction.
\end{abstract}

Keywords: Balinese Script, Augmented Reality, Extent of Satisfaction, Extent of Dissatisfaction, Canoe Model.

\begin{abstract}
ABSTRAK
Penelitian ini bertujuan untuk menganalisis impelementasi Augmented Reality (ARLearning) dalam pembelajaran Aksara Bali pada siswa usia sekolah dasar. Aksara Bali sebagai salah satu aksara daerah yang sampai saat ini menjadi salah satu tulisan daerah yang wajib diperkenalkan kepada anak-anak sekolah mulai usia Sekolah Dasar sampai dengan Sekolah Menengah Atas di Provinsi Bali. Model pembelajaran konvensional mengenalkan Aksara Bali seringkali tidak berhasil karena kurang menariknya proses pengenalan dan pembelajaran Aksara Bali tersebut. Untuk itu, diperlukan metode pembelajaran yang memanfaatkan teknologi dalam pembelajaran, salah satu nya menggunakan Augmented Reality, atau lebih dikenal dengan AR-Learning. Dengan memanfaatkan smartphone berbasis Android, pembelajaran Aksara Bali tentunya akan lebih menyenangkan siswasiswi Sekolah Dasar. Dalam peneliitian siswa-siswi kelas 3 SDN 1 B.B Agung digunakan studi kasus dalam penelitian ini. Hasil dari penelitian ini adalah kartu Augmented Reality Aksara Bali lengkap dengan analisa implementasi pembelajaran Aksara Bali berbasis Android dengan teknologi Augmented Reality menggunakan Model Kano untuk mengkategorikan atribut-atribut kepuasan pengguna AR-Learning dan Model USE Questionnaire untuk evaluasi usabilitas rekomendasi terhadap aplikasi berdasarkan 4 dimensi kualitas yaitu dimensi usefulness, ease of use, ease of learning, dan satisfaction.
\end{abstract}

Kata Kunci: Aksara Bali, Augmented Reality, Extent Of Satisfaction, Extent Of Dissatisfaction, Kano Model. 


\section{PENDAHULUAN}

Sebagai salah satu warisan budaya yang masih dikenalkan sampai saat ini dan tulisan daerah yang wajib diperkenalkan kepada anak-anak sekolah baik dari tingkat Sekolah Dasar sampai Sekolah Menengah Atas di Provinsi Bali, minat untuk membaca dan menulis Aksara Bali cenderung mengalami penurunan. Hal ini disebabkan tidak hanya metode pembelajaran Aksara Bali yang kurang menarik dalam proses pengenalan Aksara Bali, juga media yang digunakan masih mengandalkan buku. Proses pembelajaran yang diterapkan saat ini di SDN 1 B.B Agung dapat dilihat pada gambar 1 dibawah ini.

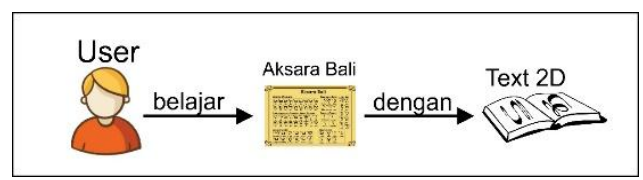

Gambar 1. Metode Pembelajaran Aksara Bali di SDN 1 B.B Agung

Seiring berkembangnya teknologi, selain buku yang berisi teks dan gambar, saat ini terdapat juga jenis-jenis buku yang dapat dipadukan dengan teknologi salah satunya Augmented reality (AR). Pertama kali ide AR diterapkan pada pada buku dengan nama Magic Book yang diteliti oleh Bilinghurst, Kato dan Poupyrev [1]. Augmented reality (AR) adalah teknologi yang menggabungkan benda maya dua dimensi dan tiga dimensi ke dalam sebuah lingkungan nyata tiga dimensi lalu memproyeksikan objek-objek virtual tersebut ke dalam waktu nyata [2]. AR digunakan untuk meningkatkan persepsi pengguna dalam kenyataan serta membantu user untuk melakukan tugas tertentu. Saat ini sudah banyak aplikasi AR digunakan dalam berbagai bidang, seperti bidang pendidikan, hiburan. Pengembangan media untuk memperkenalkan aksara Bali telah menarik beberapa peneliti dengan tujuan agar Aksara Bali lebih menarik, mudah dibaca, dan dipelajari dalam bentuk aplikasi mobile. Salah satunya adalah aplikasi mobile pengenalan Aksara Bali ke dalam huruf latin berbasis Augmented Reality yang dikembangkan oleh Pande Putu Gede Putra Pertama [3]. Dalam penelitian ini, penulis menggunakan pengujian functional suitability dan usability untuk mengetahui sejauh mana sistem dapat memenuhi kebutuhan ketika digunakan dalam proses pengenalan Aksara Bali Pengujian functional suitability juga disebut black-box testing. Teknik pengujian black-box memungkinkan untuk membuat beberapa kumpulan kondisi masukan yang sepenuhnya akan melakukan semua kebutuhan fungsional untuk program. Pengujian Functional Suitability berupaya untuk menemukan kesalahan dalam kategori berikut, fungsi yang salah atau hilang, kesalahan interface, kesalahan dalam struktur data atau akses basis data eksternal, kesalahan perilaku atau kinerja, kesalahan inisialisasi dan penghentian [4]. Usability adalah atribut kualitas yang digunakan untuk mengetahui bagaimana user interface digunakan [4]. Pengujian ini mengacu pada metode untuk meningkatkan proses desain. Berdasarkan definisi tersebut usability diukur berdasarkan komponen Kemudahan (learnability), Efisiensi (efficiency), Mudah diingat (memorability), Kesalahan dan keamanan (errors), Kepuasan (satisfaction). Hasil akhir dari penelitian ini adalah pengukuran fungsi sistem yaitu aplikasi ARLearning berbasis Android dalam penggunaan pembelajaran, khususnya respon time kamera, jarak marker dari berbagai device dengan spesifikasi berbeda. Untuk hasil analisa usability terhadap penggunaan augmented reality berbasis Android dalam proses pembelajaran aksara Bali dengan ARlearning di SDN 1 B.B Agung dengan menggunakan 4 dimensi pengukuran yaitu dimensi usefulness, ease of use, ease of learning, dan satisfaction. 


\section{TINJAUAN PUSTAKA Model Kano}

Penentuan kategori untuk tiap variabel atau Kano's Weight digunakan aturan pada Blauth's formula [5], yakni jika jumlah nilai (one dimensional + attractive + must be) $=$ jumlah nilai (indifferent + reverse + questionable) maka grade diperoleh yang paling maksimum diantara semua kategori kano yaitu (one dimensional, attractive, must be dan indifferent, reverse, questionable). Setelah dilakukan perhitungan dan analisa pengklasifikasian kategori Kano maka diperoleh jumlah/ nilai kategori kano tiaptiap atribut terhadap semua responden. Kemudian menentukan requirement tertinggi dari masing-masing item, selanjutnya menghitung presentase dan extent of satisfaction/dissatisfaction dari tiap item. Setelah melakukan perhitungan presetase dan extent of satisfaction/dissatisfaction, maka selanjutnya adalah membuat kesimpulan dan analisis hasil kuesioner. Tingkat kepuasan pengguna tergantung pada koefisian tingkat kepuasan berkisar antara 0 sampai dengan 1 , semakin dekat dengan nilai 1 maka semakin mempengaruhi kepuasan pengguna aplikasi AR-Learning, sebaliknya jika nilai mendekati ke 0 maka dikatakan tidak begitu mempengaruhi kepuasan pengguna AR-Learning dalam pembelajaran Aksara Bali.

\section{USE Questionnaire}

Metode ini merupakan Instrumen
untuk pengujian aspek Usability
menggunakan kuisioner. Pengujian ini
berupa tabel checklist yang diisi oleh
pengguna secara langsung setelah
menggunakan aplikasi. Pada kuisioner ini
terdapat 30 buah seperti yang ditunjukkan
pada tabel 1 .

Tabel 1.Instrumen Uji Usability

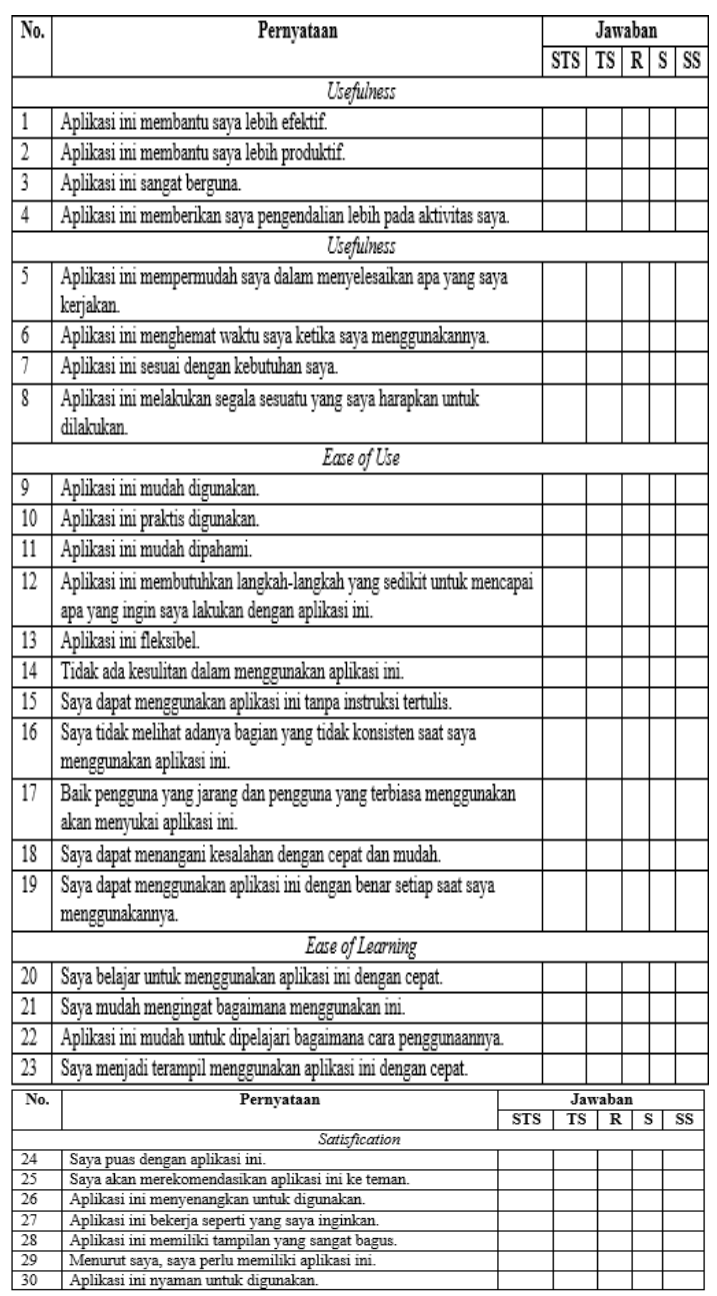

Pada pengujian aspek Usability, analisis data dilakukan cara menghitung ratarata jawaban berdasarkan skoring setiap jawaban dari kuisioner yang diisi responden. Kriteria penilaian untuk Instrument Usability menggunakan skala Likert dengan memberikan lima pilihan jawaban [4] seperti yang ditunjukkan pada tabel 2 .

Tabel 2 Interval Skala Likert Pernyataan Positif

\begin{tabular}{|c|c|}
\hline Alternatif Jawaban & Nilai \\
\hline Sangat Tidak Setuju & 1 \\
\hline Tidak Setuju & 2 \\
\hline Ragu-ragu & 3 \\
\hline Setuju & 4 \\
\hline Sangat Setuju & 5 \\
\hline
\end{tabular}


Kemudian setelah mendapat jumlah skor dihitung persentase kelayakan, sebagai berikut:

$$
\text { Persentase Kelayakan (\%) }=\frac{\text { Skor yang diobservasi }}{\text { Skor yang diharapkan }} \times 100 \%
$$

Setelah didapatkan hasil presentase, dibandingkan dengan tabel kriteria interprestasi skor seperti yang ditunjukkan pada tabel 3.

Tabel 3. Pedoman Interprestasi Skor Setelah Dikonversi

\begin{tabular}{|c|c|}
\hline Angka (dalam \%) & Klasifikasi \\
\hline $0-20$ & Sangat Tidak Baik \\
\hline $21-40$ & Tidak Baik \\
\hline $41-60$ & Cukup \\
\hline $61-80$ & Baik \\
\hline $81-100$ & Sangat Baik \\
\hline
\end{tabular}

\section{METODOLOGI PENELITIAN}

\section{Kerangka Berpikir}

Studi literature dmulai dari perancangan AR-learning untuk pembelajaran aksara Bali dengan pengambilan gambar yang akan dipakai untuk marker Aksara Bali, kemudian gambar yang akan dijadikan marker di upload ke dalam database vuforia pada link https://developer.vuforia.com/. Sebelum meng upload gambar marker, perlu dilakukan pembuatan akun di vuforia. Setelah selesai pembuatan akun, barulah semua gambar di upload ke dalam vuforia. Setelah selesai, download kembali seluruh marker berupa database vuforia. Kemudian database tersebut di import ke dalam Unity 3D untuk melakukan proses pembuatan AR selanjutnya. Untuk pengkuran sampel, lalu tabulasi hasil survey, menghitung usefulness, ease of use, ease of learning, statisfaction, dan hasil Uji Materi, lalu persentase kelayakan dan konvensi presentase kelayakan seperti yang ditunjukkan pada gambar 2 .

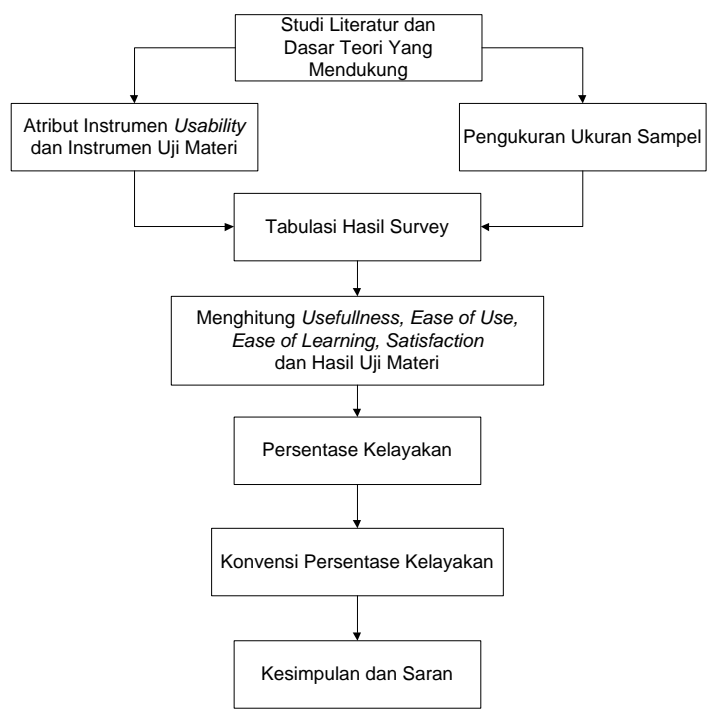

Gambar 2 Studi Literatur Instrument Usability dan Instrument Uji Materi

\section{Metode Pengumpulan Data}

Adapun jenis pengumpulan data yang digunakan dalam penelitian sebagai berikut :

1. Observasi

2. Wawancara

3. Studi Literatur

\section{Jenis Data Yang Digunakan}

1. Data Primer

Disini penulis mengambil data mengenai aksara bali pada website http://www.babadbali.com. Pada website ini dimuat penjelasan mengenai aksara bali dan bentuk penulisannya. Penulis dari website ini pun juga dari kalangan ahli aksara bali yaitu Ida Bagus Adi Sudewa. Penelitian difokuskan pada informasi umum mengenai Aksara Bali..

2. Data Sekunder

Dalam penelitian ini penulis menggunakan buku dan jurnal tentang Aksara Bali, Augmented Reality, Android, Model Kano, Model USE Questionnaire.

\section{Karakteristik Responden}

Pada penelitian ini yang menjadi responden adalah siswa kelas 3 dan guru Bahasa Bali tahun ajaran 2017/2018 di SDN 1 Baler Bale Agung dengan jumlah populasi 41 orang 


\section{Penentuan Sampel}

Penentuan sampel dalam penelitian ini menggunakan jumlah populasi dengan rumus slovin [6].

$$
\begin{gathered}
n=\frac{N}{1+N e^{2}}=\frac{42}{1+42(0,1)^{2}}=29,6 \\
=30 \text { sampel }
\end{gathered}
$$

Keterangan :

$\mathrm{n}=$ ukuran sampel

$\mathrm{N}=$ ukuran populasi

$\mathrm{E}=$ tingkat kesalahan toleransi, dalam penelitian ini ditentukan $10 \%$

Ukuran sampel model Kano yang harus dipenuhi dalam penelitian ini adalah minimum berjumlah 30 orang pengguna sampel. Karakteristik responden dapat dilihat pada tabel 4 dibawah ini.

Tabel 4. Karakteristik Responden

\begin{tabular}{|l|l|l|l|}
\hline No. & Karakteristik & Jumlah & $\begin{array}{l}\text { Presentase } \\
(\%)\end{array}$ \\
\hline 1 & Jenis Kelamin : & & \\
& Laki-laki & 14 & $46,7 \%$ \\
& Perempuan & 16 & $53,3 \%$ \\
\hline & & 30 & $100 \%$ \\
\hline
\end{tabular}

Dari hasil pengisian kuisioner tersebut, kemudian penulis menggunakan 10 sampel untuk menguji validitas dan reliabilitas pernyataan kuisioner yang penulis pakai dalam penelitian ini menggunakan tool IBM SPSS Statistics V.25. Dalam uji validitas ini, jika korelasi Pearson positif dan besarnya lebih dari 0,3 maka item yang bersangkutan dinyatakan valid, jika nilainya kurang dari 0,3 maka item yang bersangkutan dinyatakan tidak valid dan dikeluarkan dari kuesioner atau digantikan dengan pernyataan perbaikan. Dari hasil uji validitas didapatkan bahwa semua pernyataan kuisioner adalah valid $R$. Kritis diatas 0,3 dan uji reliabilitas didapatkan bahwa semua pernyataan kuisioner adalah reliabel dengan alpha cronbach diatas 0,7 yaitu 0,989 .

\section{HASIL DAN PEMBAHASAN \\ Hasil Pengujian Usability}

Pengujian usability dilakukan kepada 30 siswa kelas 3 dengan mencoba langsung aplikasi. Setelah siswa selesai mencoba aplikasi, peneliti membagikan instrumen kuisioner untuk menilai aplikasi ini layak atau tidak. Berikut hasil rekap kuisioner pengujian usability seperti yang ditunjukkan pada tabel 5 .

Tabel 5. Rekap Hasil Kuisioner Pengujian

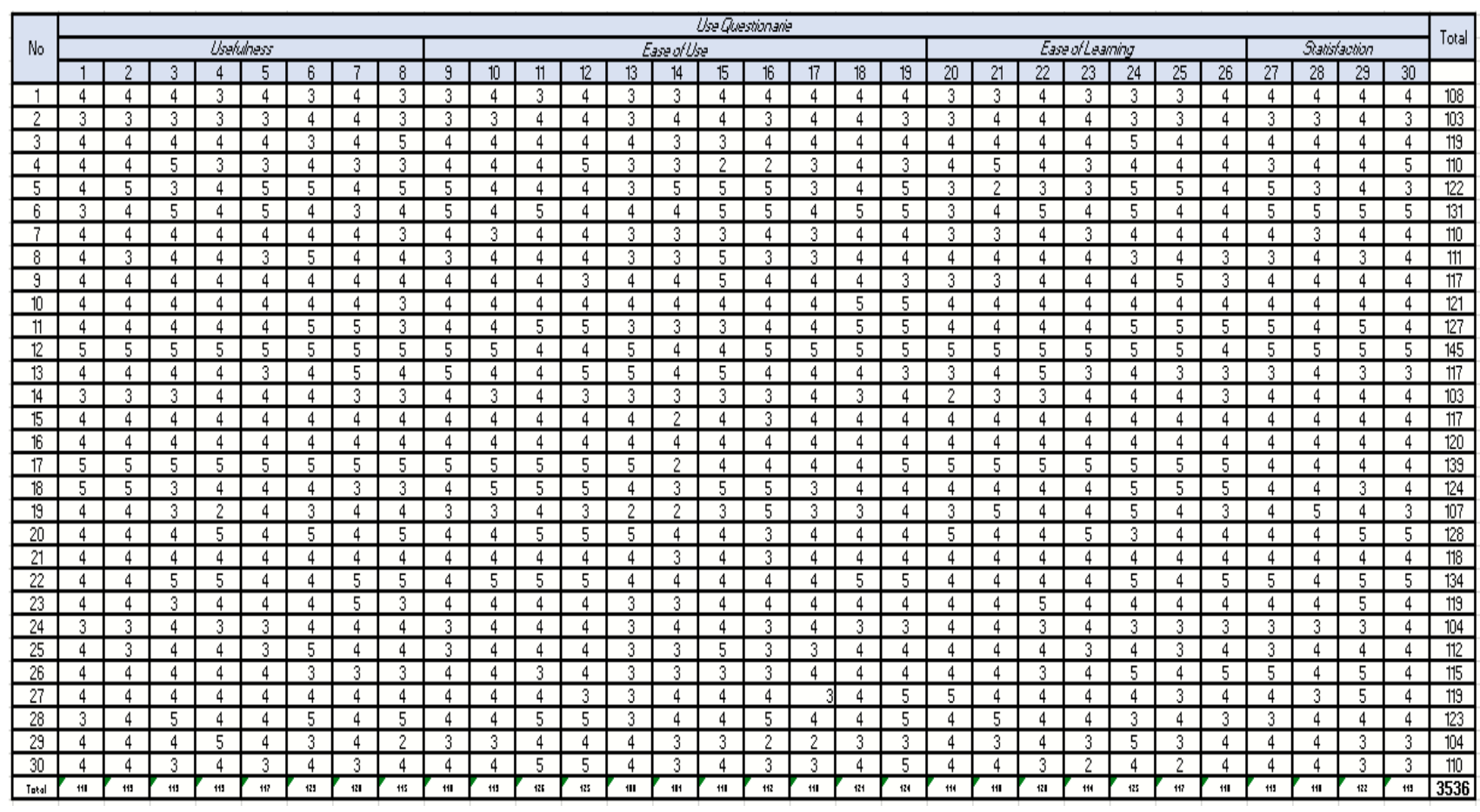


Nilai total yang didapat adalah 3.536, sedangkan nilai maksimal untuk tiap pernyataan adalah 5 (Sangat Setuju), sehingga dapat diperoleh nilai total maksimal adalah 4.500. Nilai maksimal tersebut diperoleh dari hasil perkalian jumlah responden, jumlah pertanyaan, dan nilai maksimal tiap pernyataan yaitu $30 \mathrm{x}$ 30 x $5=4500$. Setelah menentukan nilai maksimal, maka untuk persentase kelayakan usability secara keseluruhan adalah sebagai berikut:

$$
\begin{aligned}
& =\frac{\text { Skor yang diobservasi } \times 100 \%}{\text { Skor yang diharapkan }} \\
& =\frac{3536}{4500} \times 100 \% \\
& =78,58 \%
\end{aligned}
$$

Berdasarkan hasil observasi maka dapat implementaasi aplikasi AR-Learning berbasis Android dalam pembelajaran Aksara Bali memenuhi standar usability, yakni sebesar $78,58 \%$ atau dapat diklasifikasikan "Baik".

\section{HASIL DAN PEMBAHASAN}

Untuk mengetahui atribut dari aplikasi yang perlu ditingkat dan atribut mana yang sudah memuaskan didalam menggunakan aplikasi, maka 30 siswa tersebut disebarkan

\begin{tabular}{|c|c|c|}
\hline Dimensi & Atribut & Grade \\
\hline \multirow{4}{*}{$\begin{array}{c}\text { Kecepatan } \\
(\text { Speed })\end{array}$} & $\mathrm{S} 1$ & I \\
\hline & $\mathrm{S} 2$ & $\mathrm{O}$ \\
\hline & S3 & $\mathrm{A}$ \\
\hline & S4 & $\mathrm{M}$ \\
\hline \multirow{4}{*}{ Homepage } & $\mathrm{H} 1$ & I \\
\hline & $\mathrm{H} 2$ & I \\
\hline & $\mathrm{H} 3$ & $\mathrm{I}$ \\
\hline & $\mathrm{H} 4$ & $\mathrm{M}$ \\
\hline \multirow{3}{*}{$\begin{array}{c}\text { Isi } \\
\text { (Content) }\end{array}$} & $\mathrm{C} 1$ & I \\
\hline & $\mathrm{C} 2$ & $\mathrm{M}$ \\
\hline & $\mathrm{C} 3$ & I \\
\hline \multirow{3}{*}{ Konteks } & $\mathrm{K} 1$ & $\mathrm{I}$ \\
\hline & $\mathrm{K} 2$ & $\mathrm{I}$ \\
\hline & $\mathrm{K} 3$ & $\mathrm{M}$ \\
\hline \multirow{4}{*}{$\begin{array}{l}\text { Ukuran } \\
\text { Kualitas } \\
\text { Interaksi } \\
\text { (Usability) }\end{array}$} & U1 & I \\
\hline & U2 & $\mathrm{I}$ \\
\hline & U3 & I \\
\hline & $\mathrm{R} 1$ & $\mathrm{I}$ \\
\hline
\end{tabular}
kuisioner dan didapatkan hasil rekapitulasi

\begin{tabular}{|c|c|c|}
\hline \multirow{2}{*}{$\begin{array}{c}\text { Kemudah } \\
\text { Dibaca } \\
\text { (Readibility) }\end{array}$} & R2 & I \\
\hline & R3 & I \\
\hline \multirow{3}{*}{$\begin{array}{l}\text { Mobilitas } \\
\text { Data }\end{array}$} & DM1 & I \\
\hline & DM2 & A \\
\hline & DM3 & I \\
\hline \multirow{3}{*}{$\begin{array}{l}\text { Ketapatan } \\
(\text { Accuracy })\end{array}$} & A1 & I \\
\hline & $\mathrm{A} 2$ & I \\
\hline & A3 & I \\
\hline \multirow{3}{*}{$\begin{array}{c}\text { Layanan } \\
\text { Publik }\end{array}$} & PS1 & I \\
\hline & PS2 & I \\
\hline & PS3 & I \\
\hline \multirow{3}{*}{$\begin{array}{c}\text { Penggunaan } \\
\text { Platform }\end{array}$} & UP1 & I \\
\hline & UP2 & I \\
\hline & UP3 & I \\
\hline \multirow{3}{*}{ Hits } & HI1 & $\mathrm{M}$ \\
\hline & $\mathrm{HI} 2$ & I \\
\hline & HI3 & $\mathrm{I}$ \\
\hline
\end{tabular}
model Kano pada tabel 6 .

Tabel 6. Rekapitulasi Model Kano
Dari hasil tabulasi Kano Model pada tabel 6, diketahui tingkat kepuasan terhadap penerapan Augmented Reality berbasis Android dalam pembelajaran Aksara Bali seperti yang ditunjukkan pada tabel 7 .

Tabel 7. Tingkat Kepuasan Penerapan Augmented Reality Berbasis Android Dalam Pembelajaran Aksara Bali.

\begin{tabular}{|l|c|}
\hline \multicolumn{1}{|c|}{ Atribut } & $\begin{array}{c}\text { Kategori Kano } \\
\text { Model }\end{array}$ \\
\hline $\begin{array}{l}\text { A. Membuka awal } \\
\text { aplikasi }\end{array}$ & Indifferent \\
\hline $\begin{array}{l}\text { B. Membuka konten } \\
\text { aplikasi }\end{array}$ & Indifferent \\
\hline $\begin{array}{l}\text { C. Hasil pencarian } \\
\text { informasi }\end{array}$ & Must-be \\
\hline D. Unduh data & Attractive \\
\hline A. Nama Aplikasi & Indifferent \\
\hline $\begin{array}{l}\text { B. Struktur menu dan } \\
\text { Tampilan }\end{array}$ & Indifferent \\
\hline C. Fungsi Aplikasi & Indifferent \\
\hline $\begin{array}{l}\text { D. Interaksi pengguna } \\
\text { dengan aplikasi }\end{array}$ & Must-be \\
\hline A. Kualitas Aplikasi & Indifferent \\
\hline B. Relevan Aplikasi & Must-Be \\
\hline $\begin{array}{l}\text { C. Manfaat konten } \\
\text { aplikasi }\end{array}$ & Indifferent \\
\hline
\end{tabular}




\begin{tabular}{|c|c|}
\hline Atribut & $\begin{array}{c}\text { Kategori } \\
\text { Kano } \\
\text { Model }\end{array}$ \\
\hline $\begin{array}{l}\text { A. Mempunyai Link } \\
\text { dengan Aplikasi lain yg } \\
\text { terkait }\end{array}$ & Indifferent \\
\hline $\begin{array}{l}\text { B. Konten aplikasi sesuai } \\
\text { dengan tujuan }\end{array}$ & Indifferent \\
\hline $\begin{array}{l}\text { C. Terdapat informasi } \\
\text { penggunaan aplikasi } \\
\text { A. Ada ruang komunikasi }\end{array}$ & $\begin{array}{l}\text { Must-Be } \\
\text { Indifferent }\end{array}$ \\
\hline $\begin{array}{l}\text { B. Kualitas Interaksi } \\
\text { Pelayanan }\end{array}$ & Indifferent \\
\hline $\begin{array}{l}\text { C. Tampilan Mudah } \\
\text { Dimengerti (user friendly) }\end{array}$ & Indifferent \\
\hline $\begin{array}{l}\text { A. Mudah dibaca, dipahami } \\
\text { (informasi yg ada) }\end{array}$ & Indifferent \\
\hline $\begin{array}{l}\text { B. Warna dan tata letak } \\
\text { teks }\end{array}$ & Indifferent \\
\hline $\begin{array}{l}\text { C. Menggunakan Bahasa } \\
\text { Indonesia }\end{array}$ & Indifferent \\
\hline $\begin{array}{l}\text { A. Informasi dan data } \\
\text { selalu sesuai dengan } \\
\text { Aksara Bali yang diajarkan }\end{array}$ & Indifferent \\
\hline B. Data-Data Aksara Bali & Must-be \\
\hline $\begin{array}{l}\text { A. Hasil Scan Tajam dan } \\
\text { terpercaya }\end{array}$ & Indifferent \\
\hline $\begin{array}{l}\text { B. Hasil Scan Konten dapat } \\
\text { Dipertanggungjawabkan }\end{array}$ & Indifferent \\
\hline C. Tepat Sasaran & Indifferent \\
\hline A. Informasi Aplikasi & Indifferent \\
\hline B. Informasi yang lengkap & Indifferent \\
\hline $\begin{array}{l}\text { C. Layanan dan Keluhan } \\
\text { Aplikasi }\end{array}$ & Indifferent \\
\hline $\begin{array}{l}\text { A. Dukungan Device } \\
\text { Smartphone }\end{array}$ & Indifferent \\
\hline $\begin{array}{l}\text { B. Dukungan sistem } \\
\text { operasi Android }\end{array}$ & Indifferent \\
\hline A. Jumlah Pengunjung & Must-Be \\
\hline $\begin{array}{l}\text { B. Terdapat Interaksi } \\
\text { Dengan Pembuat }\end{array}$ & Indifferent \\
\hline C. Terdapat akun Pembuat & Indifferent \\
\hline
\end{tabular}

Setelah dilakukan perhitungan dan analisa pengklasifikasian kategori Kano maka diperoleh jumlah/ nilai kategori kano tiap-tiap atribut terhadap semua responden. Langkah selanjutnya adalah menentukan requirement tertinggi dari masing-masing item, selanjutnya menghitung presentase dan extent of satisfaction/dissatisfaction dari tiap item dengan menggunakan rumus sebagai berikut :
Presentase

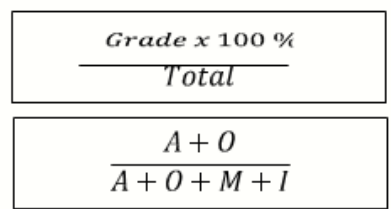

Extent of satisfaction :

$\frac{O+M}{(A+O+M+I) \times(-1)}$

Sehingga didapatkan hasil perhitungan seperti ditunjukan pada tabel 8 .

Tabel 8. Extent of Satisfaction dan Extent of Dissatisfaction

\begin{tabular}{|c|c|c|}
\hline Atribut & $\begin{array}{l}\text { SI } \\
(\%)\end{array}$ & $\begin{array}{c}\text { DI } \\
(\%)\end{array}$ \\
\hline $\mathrm{S} 1$ & 0,03 & $-0,37$ \\
\hline $\mathrm{S} 2$ & 0,63 & -1 \\
\hline S3 & 0,63 & $-0,27$ \\
\hline $\mathrm{S} 4$ & 0 & $-0,67$ \\
\hline H1 & 0 & $-0,47$ \\
\hline $\mathrm{H} 2$ & 0 & $-0,4$ \\
\hline H3 & 0 & $-0,3$ \\
\hline $\mathrm{H} 4$ & 0 & $-0,6$ \\
\hline $\mathrm{C} 1$ & 0 & $-0,37$ \\
\hline $\mathrm{C} 2$ & 0 & $-0,57$ \\
\hline C3 & 0 & $-0,37$ \\
\hline K1 & 0 & $-0,4$ \\
\hline $\mathrm{K} 2$ & 0 & $-0,23$ \\
\hline K3 & 0 & $-0,6$ \\
\hline U1 & 0,03 & $-0,23$ \\
\hline U2 & 0 & $-0,33$ \\
\hline U3 & 0 & $-0,27$ \\
\hline R1 & 0 & $-0,23$ \\
\hline $\mathrm{R} 2$ & 0 & $-0,17$ \\
\hline R3 & 0 & $-0,17$ \\
\hline DM1 & 0 & $-0,3$ \\
\hline DM2 & 0 & $-0,43$ \\
\hline DM3 & 0 & $-0,23$ \\
\hline A1 & 0 & $-0,2$ \\
\hline $\mathrm{A} 2$ & 0 & $-0,27$ \\
\hline A3 & 0 & $-0,33$ \\
\hline PS1 & 0 & $-0,2$ \\
\hline PS2 & 0 & $-0,23$ \\
\hline PS3 & 0,03 & $-0,3$ \\
\hline UP1 & 0 & $-0,17$ \\
\hline UP2 & 0,03 & $-0,17$ \\
\hline UP3 & 0 & $-0,27$ \\
\hline HI1 & 0,23 & 0,73 \\
\hline HI2 & 0,03 & 0 \\
\hline HI3 & 0 & 0 \\
\hline
\end{tabular}


Hasil dari tabel Extent of Satisfaction dan Extent of Dissatisfaction kemudian di komparasi dalam bentuk scatterplot chart seperti yang ditunjukkan pada gambar 3 .

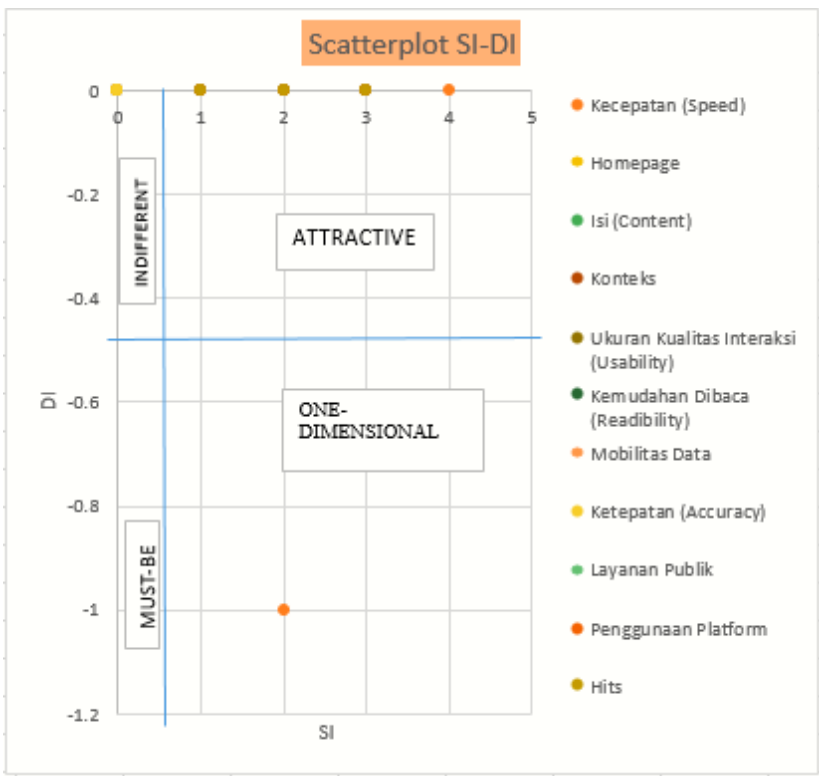

Gambar 3. Diagram Atribut Model Kano

Berdasarkan pada gambar 1, tidak ada satupun attribute yang masuk kategori mustbe, dimana aplikasi dapat dikategorikan sudah memenuhi kebutuhan pengguna. Untuk attribute speed dalam scatterplot masuk kategori one-dimensional atau performance needs, sehingga ketika diharapkan kecepatan dalam menerjemahkan marker dari kartu kedalam animasi Augmented Reality yang tampil pada smartphone tidak membutuhkan waktu yang lama. Untuk attribute lainnya masuk dalam kategori attractive, dimana tingkat kepuasan pengguna sudah sampai pada kepuasan tertinggi pada kinerja aplikasi dan tidak akan mempengaruhi pendapat pengguna walaupun ada penurunan kinerja aplikasi.

\section{SIMPULAN}

Hasil pengujian dengan model USE Questionnaire, penerapan Augmented Reality dalam berbasis Android dalam pembelajaran Aksara Bali dalam penelitian ini memenuhi standar usability, yakni sebesar 78,58\% atau dapat diklasifikasikan "Baik". Untuk model Kano, tidak ada satupun attribute yang masuk kategori must-be, dimana aplikasi dapat dikategorikan sudah memenuhi kebutuhan pengguna. Untuk attribute speed dalam scatterplot masuk kategori one-dimensional atau performance needs, sehingga ketika diharapkan kecepatan dalam menerjemahkan marker dari kartu kedalam animasi Augmented Reality yang tampil pada smartphone tidak membutuhkan waktu yang lama. Untuk attribute lainnya masuk dalam kategori attractive, dimana tingkat kepuasan pengguna sudah sampai pada kepuasan tertinggi pada kinerja aplikasi dan tidak akan mempengaruhi pendapat pengguna walaupun ada penurunan kinerja aplikasi.

\section{DAFTAR PUSTAKA}

[1] A. K. Wahyudi, R. Ferdiana and R. Hartanto, "Pengujian Dan Evaluasi Buku Interaktif Augmented Reality ARca 3D," 2014.

[2] I. G. A. Nugraha and I. K. G. D. Putra, "Rancang Bangun Aplikasi Android AR Museum Bali : Gedung Karangasem dan Gedung Tabanan," 2016.

[3] P. P. G. P. Pertama, Suyoto and T. Suselo, "Pengembangan Aplikasi Mobile Pengenalan Aksara Bali Kedalam Huruf Latin Dengan Augmented Reality," in Seminar Nasional Teknologi Informasi dan Komunikasi 2015 (SENTIKA 2015), Yogyakarta, 2015.

[4] P. D. Arista, "Pengembangan Brosur Interaktif "ARYappi” Berbasis Augmented Reality Sebagai Media Iklan SMK Yappi Wonosari," 2016. 
Feoh, Tonyjanto, Wiryadikara, Analisa Pembelajaran Aksara Bali Berbasis Augmented...327

[5] Y. N. Jayanti and M. L. Singgih,

"Peningkatan Kualitas Layanan Pengujian

Dan Kalibrasi Peralatan Kesehatan

Dengan Menggunakan Integrasi Servqual

Method, Kano Model Dan Quality

Function Deployment (QFD) (Studi

Kasus : Balai Pengamanan Fasilitas

Kesehatan Jakarta)," in Prosiding

Seminar Nasional Manajemen Teknologi

XVI , Surabaya, 2012.

[6] I. W. Pantiyasa, "Jurnal Ilmiah Hospitality Management," 1 Juli Desember 2013. [Online]. Available: http://ejournal.stpbi.ac.id/index.php/JI HM/article/viewFile/48/46.

[Accessed 10 Maret 2019].

[7] S. Defiyanti and D. C. Pardede, "Perbandingan Kinerja Algoritma ID3 Dan C4.5 Dalam Klasifikasi Spam-Mail," 2014.

[8] Jogiyanto, Analisis dan Desain, Yogyakarta: Andi, 2005.

[9] Witarto, Memahami Pengolahan Data, Jakarta: Bumi Aksara, 2008.

[10] C. P. Yanti, "Aplikasi Augmented Reality Untuk Informasi Kebudayaan Bali Berbasis Android," 2016.

[11] J. Han and M. Kamber, Data Mining Concept and Tehniques, Berlin: Springer, 2011. 